\title{
COMMUNICATION, CULTURE, DIFFERENTIATED SCHOOL EDUCATION AND ETHNOEDUCATION: INITIAL CONSIDERATIONS
}

\author{
Alceu Zoia \\ Doctorate in Education from Universidade Federal de Goiás. Adjunct Professor at Universidade \\ do Estado de Mato Grosso and the Graduate Program in Education at Universidade do Estado de \\ Mato Grosso. alceuzoia@gmail.com.
}

\section{0-0002-0512-9511}

Francisco Gilson Rebouças Porto Júnior

$\mathrm{PhD}$ in Communication and Contemporary Culture by the Faculty of Communication of the Federal University of Bahia. Professor at the Federal University of Tocantins Foundation (UFT) and the Graduate Program in Intellectual Property and Technology Transfer for Innovation (PROFNIT-UFT). gilsonportouft@gmail.com.

0000-0002-5335-6428

\section{Nelson Russo de Moraes}

$\mathrm{PhD}$ in Communication and Contemporary Culture (UFBA). Master in Social Work from UNESP, Graduated in Administration from the Toledo Educational Institution of Bauru / SP. Associate Professor of the Graduate Program in Agribusiness and Development / PGAD / FCE / UNESP / Tupã. nelsonrusso@tupa.unesp.br.

\section{0-0003-0159-9433}

When humanity begins the year 2021, it can then, in a privileged way, return an appraisal look at so many processes of interaction (social, environmental and economic) that culminated in a time of many and great challenges. The Covid-19 pandemic (SarsCov-2) caused the human being to redesign a little of his life and, you see, philosophizing a little about existence and what we bring from it most: life, faith and the knowledge; we have no doubt that this sad pandemic experience should mark a new time.

A certain optimism, with which we ended the previous paragraph, does not rule out the combative and resistance tone with which, I am sure, humanity will have to assume these new times. Science may never have been so pressured in the history of mankind (or perhaps in the age of enlightenment / Enlightenment, a few centuries after the black plague pandemic, which peaked in 1353 - although many sciences have had their cradle there). At the same time, and in Brazil in a very strong way, academic-scientific knowledge, which on the one hand is questioned and weakened by interests of power, is, on the other hand, life expectancy for all humanity.

Even without immediately resorting to the Weberian theory of domination, it is interesting to see how strong the power of knowledge in general is, be it philosophical, religious, scientific or traditional; many fear him, therefore, knowledge enlightens and emancipates by destroying political poverty and the subjugated clientelism of people and, on the other hand, knowledge is a safe 
haven for the defense of life, although, as we know, there are clumsy uses of primates.

Thus, in a world so full of challenges, the academy headed for the necessary breakdown of some endogenous cycles, goes in search of its own identity, or its reformulation in such a new context, where resistance and information are opposed to the interests of some powerful groups and the onslaught of misinformation and false news that in turn victimize society, hostage to the weakening of public policies to combat political poverty and strengthen citizenship.

This thematic dossier, part of the Observatorio Journal, is one of the fruits of an expressive movement of researchers, teachers and students who assume with courage, ethics and deep respect, the approximation between scientific knowledge and the demands of indigenous peoples (indigenous, in this case Brazilian communities) and traditional communities (among them quilombola, generizeiras, riverside and caiçaras communities, people from terreiros, leaks, people from the bottom of pastures, communities from immigration processes, extractivists and pantaneiras), within the specificities of communication, culture and ethno-education.

The field of ethno-education is present in this context, understood as an epistemological and methodological perspective of work, that is, it is a conception closely linked to the way of thinking and doing ethnography that seeks to articulate local knowledge with the educational processes developed there and / or in development.

Within this perspective of ethno-education, the actions take place in a collaborative way, where teaching and learning take place in a critical way, with the valorization of the territory in which the actions take place and the perception of work as a collective construction of the sum of the most varied voices. Thus, education is conceived as a practice that is built together, where the protagonists are teachers, students and the community itself that participate in the whole process in a collaborative way.

In this conception, ethnoducation enters as an element that seeks to achieve autonomous, critical and humanized training, always fully committed to the human being, still bringing as a central element the respect for the historical particularism and cultural diversity of the community.

The set of scientific articles selected by the evaluators (according to the metrics and academic rules determined by the journal) brings us a collection of works that, in addition to introducing readers to the thematic context of this dossier, bring important foundations for studies, research and the new scientific communications in the area in question.

The scientific article "The body in movement in the stamp: a contribution to the sensory-motor development in Physical Education in Early 
Childhood Education in Belém / PA" highlights studies on the appropriation and use of the stamp, as one of the most important cultural symbols of the Amazon and Brazil, for the process of infantile schooling. The article, which is methodologically very well structured, is part of a case study in which a teacher and six students contribute through interviews, culminating in the academicscientific understanding that the referred rhythm / dance effectively contributes to the development process, within the school.

A very interesting article, brings the intercultural school as an indigenous conquest, begins with a Latin American approach to the context of indigenous education and the challenges posed, covering the specificities of public policies in Brazil. In this sense, the article "The indigenous social movement and the conquest of the intercultural school" characterizes the school and presents its importance and challenges posed in contemporary times.

A third article, entitled "A look at the environmental management of indigenous peoples in the Legal Amazon" brings an in-depth study of public policies on indigenous territories in Brazil, in particular on PNGATI - National Policy for Environmental and Territorial Management in Indigenous Lands. It brings together studies on the Territorial and Environmental Management Plans (PGTA) of the Jamamadi (Amazonas), Yanomami (Roraima) and Waiãpi (Amapá) peoples.

The fourth article of the thematic dossier bears the title "Specific and differentiated education: cultural complexes of the Haliti-Paresi mother tongue" and circumscribes studies on the teaching of the mother tongue with the HalitiParesi ethnic group. It addresses the place of speech of the mother tongue and its cultural complexes constituted in stories, memories and in the culture itself, bringing a socio-critical look very contributing to the defense and overcoming obstacles in differentiated indigenous education.

The article "Quilombos paulistas: the public policy of ATER in interface with traditional communities in view of the state law $n^{\circ} 529 / 2020^{\prime \prime}$ revisits the challenge of quilombola communities in São Paulo, in the sense of maintaining and strengthening public policies of technical assistance of e rural extension, especially in light of the new legislation. The study concludes that the bill does not find practical legitimacy with quilombola communities and that its approval would harm food production and income generation by the communities studied.

The article "Ethnic-racial relations: social and cultural values in early childhood education" starts from Brazilian multiculturalism, which, followed by processes of violence, racism and exclusion, elevates to school many responsibilities about ethnic-racial relations experienced in the country and about how practices educational activities favor the internalization of social values that are more respectful of diversity. 
The seventh article of the dossier is entitled "Social representations: Mozambican ethnicities" and presents a study on the theory of social representations based on Social Psychology. The work studies three Mozambican ethnicities from the elements of cultures, beliefs and values, as a method uses the bibliographic review, bringing theory and socio-cultural cuttings from Mozambique.

The "Economy of the Kaingang group in the west of São Paulo in the Vanuíre Indigenous Land" is approached through a historical and ethnographic description of the Kaingang ethnic group, supported by the method of descriptive bibliography. The work brings a systematic set of information about the production of economic value and also about the business relations gradually experienced by the ethnic group under study.

The ninth article is entitled "The new coronavirus and the consequences on the mental health of health professionals involved in coping with it" and circumscribes an important contemporary theme that makes the whole society rethink public policies and socialization processes. It brings out the highlight of the professionals who are most exposed when they work on the front line of combating the disease.

The article "Active methodologies in health education for the elderly: a bibliographic review" brings an analysis of the active methodologies used in health education for the elderly, reflecting on the challenges of education being an instrument to leverage criticality and reflection, given the complexities of contemporary life.

The eleventh article, entitled "The management of the work of the Social Worker in Education Policy" brings to the debate on studies on public education policies, the importance of the Social Service professional. The documentary and bibliographic study enters the field of basic responsibilities and those contemporaneously established to the Social Worker.

The article "Active methodologies and the teaching of physical education: a literature review" was carried out within a critical line of investigation with a qualitative approach. Finally, it highlights the importance of these for stimulating creativity to build problem solutions, promoting freedom of thought.

The thirteenth article, which is entitled "On-call on the city: a study of local political participation and constitution of subjectivities through facebook", discusses the political participation of citizens through the mediation of online social networks from a group specific, based in Ouro Preto - MG.

The fourteenth work, entitled "Public policies in Brazil: systematic literature review", analyzes and communicates about the evolution of public policies in the time frame from 2010 to 2019, from the perspective of the development of participation and different actors, always from the perspective of specific thematic theory. 
Finally, the article "Advanced literary journalism and artisanal narratives: flags for research in Tourism" presents the concept of Advanced Literary Journalism - JLA and proposes the understanding of tourism as an ecosystemic plot of deterritorialization.

The organization of the chapters and the texts proposed by different researchers based on different fields of knowledge and training areas, makes this issue of Observatório Journal a multicultural trip about various realities from different academic works.

\section{References}

AZEVEDO, A. D. M. DE; NEIVA, C. R.; CHAGAS JUNIOR, E. M.; ARROYO, M. B. DE C. F. THE BODY MOVEMENT AT CARIMBÓ DANCE: A contribution to the SensoryMotor Development at Physical Education class in Early Childhood Education in Belém (PA). Revista Observatório , v. 7, n. 1, p. a1en, 1 jan. 2021.

CANÇADO, A. C.; BARROS, F. S.; BARROS, F. S. PUBLIC POLICIES IN BRAZIL: systematic literature review . Revista Observatório , v. 7, n. 1, p. a13en, 1 jan. 2021. EME, J. B.; BAPTISTA, M. L. C. ADVANCED LITERARY JOURNALISM AND ARTISANS NARRATIVES: signs for research in Tourism . Revista Observatório , v. 7, n. 1, p. a15en, 1 jan. 2021.

FERREIRA, W. A. DE A.; ZONIZOKEMAIRÔ, N. SPECIFIC AND DIFFERENTIATED EDUCATION: cultural complexes of the Haliti-Paresi mother tongue. Revista Observatório , v. 7, n. 1, p. a4en, 1 jan. 2021.

MACIEL, ÉRIKA DA S.; GOTARDELO, M.; RODRIGUES, A. L. M.; QUARESMA, F. R. P.; BARASUOL, A. M.; NASCIMENTO, L. R. DO. THE NEW CORONAVIRUS AND THE CONSEQUENCES IN THE MENTAL HEALTH OF HEALTH PROFESSIONALS INVOLVED IN THEIR COURSE. Revista Observatório , v. 7, n. 1, p. a9en, 1 jan. 2021. MORAES, N. R. DE; BERNIERI, C. G. P.; FÔLHA, J. G. P.; ALVES, L. G. P. ETHNICRACIAL RELATIONS: social and cultural values in early Childhood Education. Revista Observatório , v. 7, n. 1, p. a6en, 1 jan. 2021.

PESSOA BORGES, A. K.; BRITO, A. G. F.; BRILHANTE BATISTA, I.; MARINHO, J. DA S.; COSTA, E. B. DA S.; MELO, M. F. X. DE. ACTIVE METHODOLOGIES IN HEALTH EDUCATION FOR THE ELDERLY: a literature review. Revista Observatório, v. 7, n. 1, p. a10en, 1 jan. 2021.

PORTO JUNIOR, F. G. R.; ALVES, V. B.; OLIVEIRA, I. S. DA C.; COSTA, J. S. DA. A VIEW ABOUT THE IMPORTANCE OF THE LEGAL AMAZON INDIGENOUS PEOPLES ENVIRONMENTAL MANAGEMENT. Revista Observatório , v. 7, n. 1, p. a3en, 1 jan. 2021.

PORTO JUNIOR, F. G. R.; MARTINS, V. C.; MORAES, N. R. DE; MARCHETTI, C. T. B.; LACERDA, A. DA C. ECONOMY OF THE KAINGANG GROUP OF OESTE PAULISTA 
IN THE TERRA INDÍGENA VANUÍRE. Revista Observatório , v. 7, n. 1, p. a8en, 1 jan. 2021.

QUADRADO, J. C.; LIMA, E. SOCIAL ASSISTANT WORK MANAGEMENT IN EDUCATION POLICY. Revista Observatório , v. 7, n. 1, p. a11en, 1 jan. 2021.

QUIXABEIRA, A. P. DA S.; SILVA, A. R. A.; ARAÚJO, B. C. DE; SILVA, B. C.; ABREU, V. P. L.; BORGES, A. K. P.; FERREIRA, R. K. A. ACTIVE METHODOLOGY AND PHYSICAL EDUCATION TEACHING: a literature review. Revista Observatório, v. 7, n. 1, p. a12en, 1 jan. 2021.

RODRIGUES, H.; MELO, I. "PLANTÃO DA CIDADE": a study of local political participation and the constitution of subjectivities through Facebook. Revista Observatório , v. 7, n. 1, p. a14en, 1 jan. 2021.

SEFANE, A. F.; GOMES, J. DOS S. SOCIAL REPRESENTATIONS: Moçambican ethnicities. Revista Observatório , v. 7, n. 1, p. a7en, 1 jan. 2021.

VICENTE, E. F.; GOMES, S. C. V.; LIMA, P. G. QUILOMBOS PAULISTAS: The public policy of technical assistance and rural extension (ATER) in its interface with traditional communities in the face of São Paulo State bill n ${ }^{\circ} 529$ of 2020. Revista Observatório , v. 7, n. 1, p. a5en, 1 jan. 2021.

ZOIA, A.; CURVO, L. F. S. INDIGENOUS SOCIAL MOVIMENT AND THE CONQUEST OF THE INTERCULTURAL SCHOOL . Revista Observatório, v. 7, n. 1, p. a2en, 1 jan. 2021. 